\title{
Quantitative genetios of gene expression and methylation in the chicken
}

\author{
Andrey Höglund
}

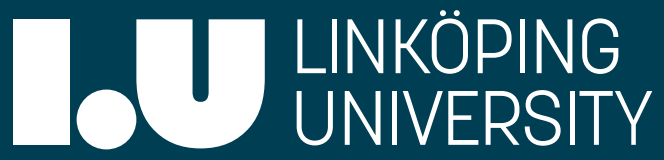


Quantitative genetics of gene expression and methylation in the chicken

\author{
Andrey Höglund
}

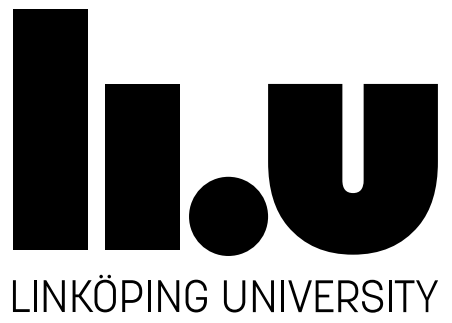

\author{
IFM Biology \\ Department of Physics, Chemistry and Biology \\ Linköping University, SE-581 83, Linköping, Sweden \\ Linköping 2020
}


Cover picture: Hanne Løvlie

Cover illustration: Jan Sulocki

During the course of the research underlying this thesis, Andrey Höglund was enrolled in Forum Scientium, a multidisciplinary doctoral program at Linköping University, Sweden.

Linköping studies in science and technology, Dissertation No. 2097

Quantitative genetics of gene expression and methylation in the chicken

Andrey Höglund

ISSN: 0345-7524

ISBN: 978-91-7929-789-3

Printed in Sweden by LiU-tryck, Linköping, 2020 


\begin{abstract}
In quantitative genetics the relationship between genetic and phenotypic variation is investigated. The identification of these variants can bring improvements to selective breeding, allow for transgenic techniques to be applied in agricultural settings and assess the risk of polygenic diseases. To locate these variants, a linkage-based quantitative trait locus (QTL) approach can be applied. In this thesis, a chicken intercross population between wild and domestic birds have been used for QTL mapping of phenotypes such as comb, body and brain size, bone density and anxiety behaviour. Gene expression QTL (eQTL) mapping was also done for tissues such as comb base, medullar bone, liver and brain. By overlapping eQTL and QTL, regions were identified associated with both the gene expression levels and the phenotypes simultaneously. In this way, a number of candidate genes, underlying variation in the above-mentioned phenotypes, were identified. Additionally, DNA methylation QTL (mQTL) mapping was done in the brain and the methylation landscape was assessed which indicated a decrease in methylation in the domestic breed. A small number of regions were identified which affected DNA methylation levels throughout the whole genome, so-called trans hotspots. Finally, DNA methylation levels were correlated with eQTL to assess the degree to which gene expression is affected by methylation, and with gene expression in general to assess the relationship between the transcriptome and methylome. Taken together, these studies link the differences observed in various phenotypes between two populations of chicken to genetic variants coupled with gene expression correlations suggesting candidate genes. DNA methylation levels were influential in regulating variation in gene expression, both positively and negatively, but gene expression was also influential in regulating the methylation level. Epi-alleles were identified which indicated genetic variants regulating methylation levels and gene expression levels either as the causal variant or in close linkage.
\end{abstract}




\section{Populärvetenskaplig sammanfattning}

I kvantitativ genetik studeras variationen i den genetiska koden (DNA) i relation med variationer i kvantitativa egenskaper. En analysmetod för detta heter QTL (på engelska; quantitative trait loci) och genom att använda besläktade individer och identifiera genetiska varianter hos dessa, kan en genetisk karta byggas. Vidare mäts egenskaper hos dessa individer och via statistiska metoder kan dessa egenskaper associeras med den genetiska kartan. På så sätt identifieras QTL-regioner. I denna avhandling har jag använt hönan som modellorganism för att kartlägga egenskaper som skiljer sig mellan den vilda och tama hönan. De egenskaper jag har valt är undersöka är storleken för hönskammen, lårbenets densitet, ångestrelaterade beteenden, äggproduktion, kroppsstorlek, hjärnstorlek och genuttryck i kam, ben, lever och hjärna. Även icke-genetiska egenskaper har undersökts i form av DNA metyleringar, vilka är metylgrupper $\left(-\mathrm{CH}_{3}\right)$ som kan återfinnas på cytosin som följs av ett guanin. Förekomsten av DNA-metyleringar influerar genuttrycksnivån beroende var någonstans i DNA:t de förekommer.

Genom att jämföra QTL-regioner för egenskaper och genuttryck kan överlapp identifieras där gener kan associeras med egenskaper. I teorin, om en genetisk variation påverkar ett genuttryck som i sin tur påverkar en egenskap bör egenskapen och genuttrycket vara associerade med samma region. Gener funna via denna metod blir då kandidater för egenskaper som undersöks.

I första artikeln genererades genuttrycks-QTL för kam och lårben som överlappades med kamstorleks-, bendensitets- och äggproduktions-QTL. Detta fann gener som associerade med kamstorlek och bendensitet. En gen fanns uttryckt i bägge vävnaderna och associerades till alla tre egenskaperna vilket tyder på en pleiotropisk effekt, alltså att en gen bidrar till flera olika egenskaper beroende på i vilken vävnad den uttrycks. Detta är ett intressant fynd eftersom fåglar använder kalcium lagrat i lårbenet för att producera äggskal och en högre densitet i lårbenet skulle generera flera ägg. Kammens storlek blir då en indikator på att en större mängd ägg kan läggas och på så sätt ett ornament för sexuell selektion.

I andra artikeln undersöktes komplexa egenskaper i form av ångestladdade beteenden. Individer testades i en arena för hur lång tid det tar för dem att uppsöka en annan höna, med förutsättningen att en rädd höna skyndar sig till sina artfränder. Dessa beteende-QTL överlappades med genuttrycks-QTL för hypotalamus då denna hjärnregion ansvarar för bland annat reglering av rädsla. Ett par kandidatgener identifierades och kan agera som bas för vidare forskning inom gener knutna till ångest, även hos människan.

I tredje och fjärde artiklarna undersöktes kropps- och hjärnstorlek. Den vilda och tama hönan skiljer sig avsevärt i storlek för bägge egenskaperna. Kroppsstorleks-QTL överlappades med genuttrycks-QTL för levern, som är ett metaboliskt aktivt organ och reglerar hunger med hjälp av det centrala nervsystemet. Totalt identifierades fem kandidatgener som påverkar kroppsstorleken. Vidare överlappades kroppsstorlek- och hjärnstorleks-QTL med genuttrycksQTL för storhjärnan (cerebrum). Storhjärnan ansvarar för att uppfatta omvärlden (bland annat hörsel och syn) och en större storhjärna ökar denna kapacitet. Kandidatgener hittades även här för både kropps- och storhjärnastorlek. Slutligen testades genuttryckets-QTL mellan lever, storhjärnan och hypotalamus där ett större överlapp hittades mellan lever och 
hjärnregionerna än inom hjärnregionerna. Detta skulle stödja hypotesen om att hjärnregioner kan utvecklas var för sig beroende på selektionstryck, snarare än att alla hjärnregioner utvecklas tillsammans.

I artikel fem undersöktes DNA metyleringsprofilen i hypotalamus, där stora delar av DNA:t visade sig ha en minskad andel metylering i den tama jämfört med den vilda hönan. Vidare hittades ett fåtal genetiska regioner som kontrollerade många metyleringsnivåer spridda över hela DNA:t. Även dessa hade en minskad andel metylering i den tama hönan. För att få en bättre förståelse för hur DNA-metylering påverkar genuttryck i hönan, överlappades DNA metylerings-QTL med genuttrycks-QTL för hypotalamus. En korrelation hittades där metylering bidrog till att förklara variationen i genuttrycksnivån, vilket innebär att även den icke-genetiska faktorn bör inkluderas för att förklara skillnader i genuttryck i framtida studier. Slutligen överlappades beteende-QTL (artikel två) med metylerings- och genuttrycks-QTL för hypotalamus. En kandidatgen identifierades som korrelerade med ångestbeteende. Alltså, en egenskap som är associerad med en gen och genuttrycket är associerat med metyleringsnivån. Ett intressant fynd som visar på komplexiteten i biologiska system i kontrollen för något så abstrakt som beteenden. 


\section{Papers}

I. Johnsson M, Rubin C. J, Höglund A, Sahlqvist A. S, Jonsson K. B, Kerje S, Ekwall O, Kämpe $\mathrm{O}$, Andersson L, Jensen $\mathrm{P}$, Wright $\mathrm{D}$. The role of pleiotropy and linkage in genes affecting a sexual ornament and bone allocation in the chicken Molecular Ecology 23, 2275-2286

https://doi.org/10.1111/mec.12723

II. Johnsson M, Henriksen R, Fogelholm J, Höglund A, Jensen P, Wright D. Genetics and Genomics of Social Behavior in a Chicken Model. Genetics 209, 209-221 (2018) https://doi.org/10.1534/genetics.118.300810

III. Johnsson M, Henriksen R, Höglund A, Fogelholm J, Jensen P, Wright D. Genetical genomics of growth in a chicken model. BMC Genomics 19, 72 (2018) https://doi.org/10.1186/s12864-018-4441-3

IV. Höglund A, Strempfl K, Fogelholm J, Wright D, Henriksen R. The genetic regulation of size variation in the transcriptome of the cerebrum in the chicken and its role in domestication and brain size evolution. BMC Genomics 21, 518 (2020) https://doi.org/10.1186/s12864-020-06908-0

V. Höglund A, Henriksen R, Fogelholm J, Churcher A. M, Guerrero-Bosagna C. G, MartinezBarrio $A$, Johnsson $M$, Jensen $P$, Wright $D$. The methylation landscape and its role in domestication and gene regulation in the chicken. Nat Ecol Evol, (2020) https://doi.org/10.1038/s41559-020-01310-1

Paper I is reprinted with permission from John Wiley \& Sons.

Paper II, III and IV are published under the Creative Commons Attribution 4.0 licence. 


\section{Papers not included in the thesis}

Edstam M. M, Laurila M, Höglund A, Raman A, Dahlström K. M, Salminen T. A, Edqvist J, Blomqvist K. Characterization of the GPI-anchored lipid transfer proteins in the moss Physcomitrella patens. Plant Physiol. Biochem. 75, 55-69 (2014)

https://doi.org/10.1016/j.plaphy.2013.12.001

Schwochow Thalmann $D$, Ring $H$, Sundström $E$, Cao $X$, Larsson $M$, Kerje S., Höglund $A$, Fogelholm J, Wright D, Jemth P, Hallböök F, Bed'Hom B, Dorshorst B, Tixier-Boichard M, Andersson $\mathrm{L}$. The evolution of Sex-linked barring alleles in chickens involves both regulatory and coding changes in CDKN2A. PLoS Genet. 13 (2017)

https://doi.org/10.1371/journal.pgen.1006665

Bélteky J, Agnvall B, Bektic L, Höglund A, Jensen P, Guerrero-Bosagna C. Epigenetics and early domestication: Differences in hypothalamic DNA methylation between red junglefowl divergently selected for high or low fear of humans. Genet. Sel. Evol. $\mathbf{5 0}$ (2018) https://doi.org/10.1186/s12711-018-0384-z

Fogelholm J, Inkabi S, Höglund A, Abbey-Lee R, Johnsson M, Jensen P, Henriksen R, Wright D. Genetical Genomics of Tonic Immobility in the Chicken. Genes 10, 341 (2019) https://doi.org/10.3390/genes10050341

The following article is a preprint and has not been certified to peer review

Henriksen R, Höglund A, Fogelholm J, Abbey-Lee R, Johnsson M, Dingemanse N, Wright D. Intra-individual behavioural variability: a trait under genetic control https://doi.org/10.1101/795864 


\section{Introduction}

Understanding the function of a gene product, a protein, is a complex task as the function varies between tissues and is also dependent on which other factors interact with the protein itself. Realising that the protein affects the endocrine or central nervous system, which interacts with multiple tissues to generate a sought-after trait, complicates this matter further. A first step towards annotating a gene is to associate its function with a trait. Gregor Mendel (1822-1884) showed that simple traits such as colour and morphology of garden pea seeds could be inherited from parents to offspring, today known as Mendelian law of inheritance. This law states that a gene can exist in alternative copies (also known as alleles) on a certain position on the chromosome (also known as locus) and the inheritance of traits can be predicted mathematically in a population. In this thesis, I use the chicken as a model organism to dissect complex traits, such as behaviour, growth and size variations of various physical traits and correlate these against measured gene expression levels from tissues such as brain, liver, bone and comb. The genome-wide DNA methylation pattern is also investigated to better understand the mechanism of this epigenetic modification, its presence in the genome and how it influences gene expression levels.

\section{Correlating a region on the genome with a phenotype - QTL}

If a variation observed in a trait is linked to a genetic variation, then the genetic variation can serve as a marker. If this marker also segregates and becomes fixed between two subpopulations a correlation between the marker and genetic variation can be sought after. These markers (also known as genetic markers) are polymorphic (poly-many, morphs - forms) and include microsatellites, short and long tandem repeats, restriction fragmentation repeats and single nucleotide polymorphisms. I will focus on the latter. Single nucleotide polymorphism, SNPs, are substitutions of nucleotides on a specific position in the genome and using sequencing arrays they are readily detectable.

Phenotype (pheno - showing, type - type) is an observed trait or characteristics of an individual. The majority of phenotypes are continuous, such as height, weight, amount of gene product produced, behaviour, DNA methylation levels - and thus are quantitative. By identifying phenotypic differences between populations coupled with genetic variation, it is possible to map these phenotypes to specific loci on the genome. The method devised for this is termed 'Quantitative Trait Loci' (QTL) and has been used since 1976 (Soller et al., 1976) and was further improved in 1989 as the 'interval mapping' procedure was introduced (Lander and Botstein, 1989). In this thesis phenotypic QTL, gene expression QTL (eQTL) and DNA methylation QTL (mQTL) have been used extensively, identifying loci associated with the phenotype in question. At its core QTL analysis harness the power of recombination events to reduce linkage disequilibrium between genetic markers, i.e. shuffling parts of the genome between the parental chromosomes generating a new assortment of genetic regions being passed on to the next generation. These genetic markers are scored for each individual and used as a predictor variable in a linear regression model with the phenotypes values as the response variables. With interval mapping it is possible to estimate the genotype between the scored markers as well. A logarithm of odds (LOD) profile is calculated throughout the genome with peaks in the profile considered as QTL. The LOD is a score of the likelihood of observing 
the data linked to the loci rather than observing the same data by chance. The maximum likelihood is thus found in the peaks. The threshold for which QTL are significant is commonly calculated using a permutation test (Churchill and Doerge, 1994; Doerge and Churchill, 1996). Finally, the locations of these markers on the genome are referred to in terms of genetic distance. Unlike a physical map, which specifies the physical location on the chromosome, genetic map distances are measured by the rate of recombination events during meiosis. The distance between two markers is measured in centiMorgans (cM) where $1 \mathrm{cM}$ corresponds to $1 \%$ chance that the two markers will be separated due to recombination in a single generation (Broman and Sen, 2009).

To allow the recombination events to occur in a controlled manner, experimental crosses can be setup using phenotypically different parental breeds and intercrossing the offspring within each subsequent generation. A number different of experimental crosses that can be used one of them being the advanced intercross lines (AIL). For the papers included in this thesis an AIL of the eighth generation was used. As recombination events occur between each generation, the greater the generation number the higher the resolution of the genetic map will be. The starting parental generation was three domestic White Leghorn (WL) females and one red junglefowl (RJF) male originating from Thailand. The RJF male is considered as wildtype, while the WL females have been breed and selected for egg-laying. As chickens were domesticated around 8000 years ago from a sub-population of red junglefowls originating from south-east Asia (Fumihito et al., 1994), this experimental cross serves as an avenue for studying domestication in chickens, with multiple phenotypes differing between the two populations, such as brain mass, body mass and behaviour, but also in the transcriptome and methylome.

\section{Identifying genes affecting the phenotype}

Having identified a phenotypic QTL it becomes tempting to identify genes within the region that directly affect the phenotype, as this would bring improvements to selective breeding, allow for transgenic techniques to be applied in agricultural settings and assess the risk of polygenic diseases (Falconer and Mackay, 1996). An extended approach of 'genetical genomics' (De Koning and Haley, 2005; Schadt et al., 2003) for identifying these genes is used in this thesis by overlapping phenotypic QTL with eQTL. In theory, if a genetic variant affects gene expression that in turn affects a molecular pathway that in turn affects a phenotypic trait, the phenotypic value and the gene expression level would be associated with the same genomic region. Additionally, the phenotypic value and the gene expression level are correlated in a linear model further reducing the number of candidate genes in the region. However, finding a correlation is not the same as causality and validation studies are needed to confirm functional causality. CRISPR/Cas9 system is one such gene cloning method where loss-of-function mutants can be generated and gene function validated (Jaganathan et al., 2020; Jinek et al., 2012). This requires a laboratory setup not within the scope of my current project. An alternative computational method is directional causality using the Network Edge Orienting (NEO) software (Aten et al., 2008). NEO implements structural equation models (SEM) to fit multi-trait causal models in a trait network to find directionality between the phenotypes. Genetic markers from the QTL are used as edges for the phenotype network and the directionality (if any) of the phenotypes associated with the QTL is investigated. These local edge models are tested for directionality separately by a chi-square test with one degree 
of freedom, e.g. phenotype $A$ is causing phenotype $B$. The $p$-value from the next best model is then divided with the $p$-value of best model multiplied with log 10 generating a leo.nb.score (Local SEM-based Edge Orienting Next Best score). Depending on the number of genetic markers used, different thresholds have been suggested by the authors; leo.nb.SingleMarker $>1.0$, leo.nb.cpa $>0.8$ (the same marker for both QTL tested), and leo.nb.oca > 0.3 (different markers for both QTL tested). Using the NEO software, it is possible to assess if the phenotype is affecting the gene expression or if the gene expression is affecting the phenotype.

The analysis pipeline described above has been used throughout the thesis, i.e. QTL mapping a phenotype of interest coupled with eQTL mapping of genes in a relevant tissue in the same individuals. These QTL are overlapped with the eQTL and thereafter phenotype values and gene expression levels found within the overlap are linear regressed and finally tested for causal directionality.

\section{Non-genetic gene regulation - Epigenetics}

Epigenetics is the study of changes made to gene expression levels, and ultimately the phenotype, that are not mediated by changes in the DNA sequence. These changes should also be heritable mitotically and/or meiotically (Dupont et al., 2009). Coined first by Conrad Waddington in the 1950s the term concerned events that could not be understood with genetic principles (Goldberg et al., 2007), such as the process from which a zygote transformed into a multicellular complex organism (Waddington, 1956). Today the paradigm tells that each somatic cell contains the same DNA composition and can by altering the gene expression levels differentiate into distinctive tissues (Berger et al., 2009; Felsenfeld, 2014). These gene expression profiles within a cell are induced by chemical modifications, such as DNA methylation, structural protein configurations (histone and chromatin modifications) and even regulatory RNAs with micro-RNA, small-interfering RNA and noncoding RNA that are able to regulate the quantity of protein produced. The epigenetic modification studied in this thesis is DNA methylation which is a methyl-group $\left(-\mathrm{CH}_{3}\right)$ added to the fifth carbon on a cytosine that is followed by a guanine. These regions are termed CpG-sites (5'-cytosine-phosphate-guanine$\left.3^{\prime}\right)$ and are commonly found in promoter regions (Irizarry et al., 2009; van Eijk et al., 2012) and in transposable elements (Bestor, 1990). Studies have demonstrated a negative correlation between the presence of DNA methylation in the promoter and gene expression level, most likely by interfering with binding sites of transcription factors (Bird and Wolffe, 1999; Docherty et al., 2012). Contrarily, hypermethylation of the gene body has a positive correlation with gene expression levels (Lorincz et al., 2004).

Besides gene expression levels, a variety of biological processes are affected by DNA methylation such as genomic imprinting, sex chromosome inactivation in mammals, cell differentiation, protection against invading DNA molecules and development (Bird, 2002). The presence of DNA methylation within the eukaryotic domain varies in an unclear manner. In the nematode Caenorhabditis elegance and the yeast Saccharomyces cervevisiae (Simpson et al., 1986) no DNA methylations have been found. However, the parasitic nematode Trichinella spiralis show evidence of functional DNA methylation (Gao et al., 2012), perhaps due to it having life cycle events within mammalian hosts. In mammals, genome-wide DNA methylation is unevenly distributed. Hypermethylation usually occurs at heterochromatin, repetitive sequences and transposon regions, while regions next to genes are hypomethylated relative 
the gene body (Eckhardt et al., 2006; Li et al., 2011). In the majority of cases, DNA methylation patterns in chickens are similar to those in mammals where the majority of $\mathrm{CpG}$ isolated regions ( $\mathrm{CpG}$ islands) are unmethylated, repetitive sequences are hypermethylated (Li et al., 2011), and $80 \%$ of all promoters in chickens are methylated (Nätt et al., 2012). The classical pattern of DNA methylation around and within genes observed in mammals is also observed in chickens (Li et al., 2011) and the great tit (Laine et al., 2016), where regions flanking the gene show relatively lower methylation levels than the gene body.

A set of genes have been identified responsible for DNA methylation preservation, the DNA methyltransferase (DNMT) family. The DNMT family is composed of genes responsible for de novo methylation (DNMT3a and DNMT3b) and maintaining DNA methylation (DNMT1) during DNA replication. Additionally, DNMT2 has been shown to exhibit some yet unclear DNA methyltransferase activity and DNMT3L has some catalytic activity of DNMT3s (Klose and Bird, 2006). On the molecular level DNMT3s convert the cytosine in a CpG-site to 5-methylcytosine and due to CpG arrangement the methylations are sitting diagonally to each other on the opposing DNA strands. The DNMT family is also represented in the chicken genome, where DNMT3b is located on chromosome 20, DNMT3a on chromosome 3 and DNMT1 on one of the microchromosomes (Yu et al., 2008).

\section{Methods for identifying gene expression and DNA methylation}

Two types of genomic assays were used for this thesis, microarrays and methylated DNA immunoprecipitation sequencing (MeDIP-seq). The microarray assay use extracted messenger RNA (mRNA) that is reverse transcribed into complementary DNA (cDNA). This cDNA is labelled with a fluorophore and is hybridised onto a glass array which has been pre-fitted by a vendor with probes of known genes. The fluorescence levels are measured and a relative gene expression level is obtained. For the DNA methylation levels an antibody assay was used where the DNA was fragmented into $800-1000 \mathrm{bp}$ fragments and treated with an antibody specific for methyl-5-cytocine. Each fragment bound to an antibody was collected, purified and sent for sequencing. The sequence reads were then aligned to the reference genome and regions with strong methylations are occurring more frequently. The level of DNA methylation is relative. 


\section{The role of pleiotropy and linkage in genes affecting a sexual ornament and bone allocation in the chicken}

In paper I the linkage between comb mass and the medullar bone density in the chicken was investigated. QTL mapping was done for bone allocation and gene expression in the medullar bone tissue, and gene expression in comb base tissue using multiple experimental crosses and assessing the loci in common. By comparing comb mass QTL (identified in a previous study: (Johnsson et al., 2012)) and the bone allocation QTL, 11 overlapping loci were identified. These loci were further overlapped with the eQTL from comb base tissue and four candidate genes were identified ( $F N D C 3 A, R G C 32, H A O 1$ and EMC7). These genes correlated with comb mass and also had an eQTL. Further, RGC32 and EMC7 expression levels also correlated with bone allocation traits (bone density and area). These genes were also correlated against fecundity traits (egg production) with HAO1 having a correlation. Finally, the eQTL mapping for the medullar bone found eQTL for HAO1. Taken together, these genes are differently expressed in both bone and comb base tissue and are correlating with the respective phenotypes, which indicates a pleiotropic effect.

\section{Genetics and Genomics of Social Behaviour in a Chicken Model}

In paper II social behaviour was mapped to the chicken genome. Social reinstatement, a social and anxiety related behaviour, was measured and 24 QTL are identified. From a previous study (Johnsson et al., 2016) gene expression was measured in the hypothalamus tissue using microarray and eQTL mapped. The social reinstatement QTL and hypothalamus eQTL were overlapped identifying five candidate genes (ACOT9, SRPX, PRDX4, TTRAP and an EST $603866246 \mathrm{~F}$ ) which correlate with a social reinstatement trait and also had eQTL. These genes were further tested in a structural equations model analysis (NEO software) to assess directional causality between gene expression and the behaviour. ACOT9, the EST 603866246F and TTRAP were all significant.

\section{Genetical genomics of growth in a chicken model}

In paper III genes affecting growth in the chicken were sought-after. Body mass (as an indicator of growth) was measured at three time-points in life and were QTL mapped. Gene expression was measured in liver tissue using microarray and were eQTL mapped. The liver serves as a proxy to identify growth correlations as this metabolically active organ interacts with both hunger sensation through the CNS and the metabolism of hormones, carbohydrates, fats and lipids. In total, 16 loci are identified that affected growth. From a previous study (Kerje et al., 2003) a region on chromosome 1 was identified as growth 1 which is associated with growth traits in chickens. An overlap was identified with growth1 in this study also. Furthermore, 13 liver trans eQTL hotspots are identified of which one was within the growth1 region. Finally, five candidate genes (YEATS4, OSBPL8, TRAK1, CEPS5 and 
PIP4K2B) were identified that affect growth by overlapping growth QTL with liver eQTL. Of these, YEATS4 and OSBPL8 also overlapped the growth1 region.

\section{The Genetic Regulation of size Variation in the Transcriptome of the Cerebrum in the Chicken and its role in domestication and brain size evolution}

In paper IV the genetic architecture underlying cerebrum size were investigated in the chicken. From a previous studies, QTL for body mass (paper III) and cerebrum mass (Henriksen et al., 2016) were identified. Gene expression was measured in the cerebrum tissue using microarrays and eQTL mapped. The body mass and cerebrum mass QTL were overlapped with the cerebrum eQTL and one candidate gene was identified for cerebrum mass (MTF2 involved in anterior CNS development) and two for body size (PCBD2 and an EST 603848039F1 mapping to $R C H Y 1$ ). These genes were also directionally causal using the structural equational model analysis (NEO software). Additionally, gene expression profiles were compared between the cerebrum, hypothalamus (previous study: (Johnsson et al., 2016)) and liver (paper III) tissue, which showed a greater overlap of eQTL between the somatic tissue and the respective brain parts, than between the two brain parts. This suggests that brain sub-regions evolve independently and are functionally driven, rather than coupled by developmental constraints.

\section{The Methylation Landscape and its role in Domestication and Gene Regulation in the Chicken}

In paper $\mathbf{V}$ the interaction between the epigenetic and genetic regulation was investigated, to determine how it affects gene expression, influences behaviour and also its effect on the domestication process in the chicken. MeDIP-seq was used to map DNA methylation profiles for the hypothalamus tissue. A high abundance of $\mathrm{MQTL}$ was identified where local (cis) mQTL blocks were observed with higher DNA methylation levels in regions with the RJF genotypes compared to WL genotypes. Additionally, 13 regions were identified which were affecting DNA methylation across multiple chromosomes. These regions were also observed to have higher methylation for the RJF genotype. To assess the effect DNA methylation has on gene expression, eQTL from hypothalamus tissue (Johnsson et al., 2016) were overlapped with the DNA methylation profile in the same tissue from the same individuals in a linear regression model. Correlation of 435 probesets was identified. Further, the genotype was included in the linear model and on average $15 \%$ of gene expression variation could be explained by the genetic component, while DNA methylation explained 7,7\%. Additionally, a test for epi-allelic imbalance found 12 genes which contained one or more SNPs which in the heterozygote state were differently methylated. Finally, a correlation between the social reinstatement associated gene TTRAP (paper II) and the tonic immobility associated gene CA8 (from a previous study: (Fogelholm et al., 2019)) was observed, as these genes' expression was correlated with DNA methylation. 


\section{Discussion}

This thesis uses an advanced intercross of domestic WL and wild-derived RJF chickens to generate eQTL in the bone, comb base, liver and cerebrum tissue, MQTL in the hypothalamus tissue and phenotypic QTL for bone density and social reinstatement behaviour. Coupled with eQTL and phenotypic QTL from previous studies on the same advanced intercross a list of candidate genes has been produced. I paper I, four candidate genes correlated with both the comb mass and had significant eQTL in the comb base tissue; FNDC3A, RGC32 (chromosome 1), HAO1 (chromosome 3) and an expression sequence tag near the gene EMC7 (chromosome 5). These eQTL/QTL overlaps were not tested with the NEO software and only give us associations. Measuring the gene expression of these genes in the medullar bone tissue RGC32 did not have an eQTL, while HAO1 did. RGC32 and EMC7 correlated with bone allocation (bone density and area) while $H A O 1$ correlated with fecundity phenotypes such as egg production. Comb mass has been identified as a true sexual ornament indicating fitness as its mass correlates positively with egg production (Wright et al., 2008). The overlap between comb mass and bone density has also been shown to correlate positively (Johnsson et al., 2012), as the medullar bone serves as a calcium reservoir in the chicken to be used during egg production. Further, an F2 cross have found overlap between comb mass QTL and bone allocation QTL (Wright et al., 2010). These findings indicate a trend towards pleiotropy (or extremely strong linkage) and with the power of an advanced intercross the loci of interest have been shrunk to prune the number of candidate genes.

For the social reinstatement experiment (paper II) three directionally causal candidate genes were identified: ACOT9 (chromosome 1) and the EST 603866246F (chromosome 2) both were causal for the minimum time spent in the start zone while TTRAP (chromosome 2) was causal for minimum, maximum time spent in start zone and average time in the start zone. ACOT9 is an enzyme involved in hydrolysing acyl-coenzyme $A$ thioesters and a loss of function of AcylCoA thioesterases may be involved in neuronal degradation (Kirkby et al., 2010). TTRAP is a DNA phosphodiesterase and protects against DNA damage (Zeng et al., 2011). Additionally, it has been associated with early-onset of Parkinson's disease (Zucchelli et al., 2009) and might protect against neuro-degradation. TTRAP has a human ortholog (known as TDP2) which is required for normal neural function (Gómez-Herreros et al., 2014). Taken together these candidate genes have neural connections and serves as a good starting point to further investigate anxiety related behaviours.

In the liver paper (paper III), growth was investigated and five candidate genes were identified: OSBPL8, YEATS4 (chromosome 1), TRAK1 (chromosome 2), CEPS5 (chromosome 6) and PIP4K2B (chromosome 26). OSBPL8 is a gene interacting with oxysterols, which affects lipid levels in liver and blood in transgenic mice (Zhou et al., 2011) while YESATS4 is involved in cell proliferation and gene regulation (Park and Roeder, 2006). TRAK1 and CEP55 are both involved with microtubules activity in mitochondria (Ogawa et al., 2014) and during cell division (Zhao et al., 2006), respectively. PIP4K2B phosphorylates phosphatidylinositol 5phosphate which is involved in cell proliferation in cancer cell lines (Luoh et al., 2004). Moreover, YEATS4 and OSBPL8 also overlapped the growth1 region, a region found on chromosome 1 which has been identified previously and explains $9 \%$ of the size variation in the chicken (Kerje et al., 2003). As directional causality was not tested in this analysis it becomes speculative to say if body mass is affecting the gene expression or the reverse. 
However, covariance was observed. Interestingly, YESATS4 and PIP4K2B were found to be involved with cell proliferations, while OSBPL8 seems to interact with a pathway regulating lipid levels in the blood serving as good indicators for growth.

The different brain regions in chickens have also grown in size during domestication, both proportionally and absolute (Henriksen et al., 2016; Iwaniuk and Hurd, 2005; Rehkämper et al., 2008). For the size difference in cerebrum one directionally causal candidate gene was identified MTF2. MTF2 (also known as $\mathrm{Pcl} 2$ ) is a metal response element binding transcription factor that selectively binds to unmethylated DNA (Perino et al., 2018) and is involved in brain development as it regulates the development of the anterior central nervous system (FunckBrentano et al., 2001). Understanding how a brain gains size is highly interesting as its size provides increased processing power i.e. in the speed and efficiency of processing information (Burish et al., 2004; Henriksen and Wright, 2017)

With so many transcriptomes measured on this AIL (cerebrum, liver and hypothalamus) it was feasible to investigate the two main hypothesis regarding brain size evolution (Montgomery et al., 2016); (1) the developmental constraints hypothesis which states that brain regions evolve together in size as they are limited by the same underlying developmental and genetic mechanisms during neurogenesis and (2) the functional constraints hypothesis which states that brain regions undergo independent development and co-evolution of size is due to mainly functional restrains between brain regions as the underlying mechanism is more complex, forming a more mosaic brain composition. Thus, overlapping the eQTL from cerebrum, liver and hypothalamus tissue, a greater overlap between genes were observed between the respective brain regions and the liver. As functionally similar tissue should have similar basal functions, more similarity is expected between the brain regions that between the brain and the liver. Thus, this result suggests the functional constraint brain evolution hypothesis. By overlapping the eQTL hotspots (regions with increased number observed eQTL than by chance) two genes were found of which one (GEMIN2) is involved in the neural crest cell activity (Rogers et al., 2013; Yasumi et al., 2016), suggesting the developmental constraint brain evolution hypothesis. Interestingly, a combination of both these brain evolution hypothesis have been suggested before (Gutiérrez-lbáñez et al., 2014; Hoops et al., 2017; Moore and Devoogd, 2017).

It is important to remember that gene expression studies hinge on the fact that gene expression levels are in constant change due to feedback systems (Mitrophanov and Groisman, 2008) or even more predictable cycles as the circadian rhythm (Damiola et al., 1998). Thus, capturing the gene expression levels in the correct moment to explain a phenotype is challenging. Furthermore, identifying the correct tissue to correlate the gene expression to a phenotype such as behaviour, increases the complexity of explaining the phenotype in question. In addition, when studying complex phenotypes a large number of genes interact with small effects contributing to the phenotype and thus the power comes with the number of individuals studied and variation in the starting parental (Falconer and Mackay, 1996). Although, I did find a respectable amount of candidate genes the fact still remains that many were inevitable failed to be identified, with the reasons mentioned above. 


\section{The methylome in the chicken}

The transcriptional differences observed in the advanced intercross were large and the same was observed for the epigenetic modification of DNA methylation. Continuous adjacent regions were observed to have decreased DNA methylation levels for the WL genotypes compared to the RJF. The same was observed for the trans hotspots, where a few regions scattered across the genome were correlating with decreased DNA methylation levels for the WL genotype. These results indicate that the domestication process hypomethylated these regions. Moreover, on average $15 \%$ of the gene expression variation could be explained with the genetic variance, while $7,7 \%$ of the variance was accounted to the DNA methylation levels. An interesting observation which begs the question if other epigenetic modifications, such as histone modifications and non-coding RNA, could be included to explain an even larger proportion of the variance.

The prevalence of mQTL and eQTL trans hotspots could be explained with regulatory elements controlling multiple regions, or the fact that chromatin structures are three-dimensional and with different folding patterns place regions that are linearly far apart on the chromosomes more adjacently (Atkinson and Halfon, 2014). Thus, it would be interesting to include chromatin immunoprecipitation sequencing (ChIP-seq) analysis in combination with trans MQTL and eQTL to further investigate trans hotspots.

Combining mQTL, eQTL and the sequence data for the MeDIP, 'epi-allelic imbalance' was detected. The phenomenon of allelic imbalance occurs when regulatory elements affect gene expression and alleles are expressed in different ratios in the same individual. In RNA sequencing it is possible to detect allelic imbalance in heterozygote regions. As the MeDIP-seq protocol bind to methylated cytosine in a CpG it should be possible to detect epi-allelic imbalance when comparing methylated regions in heterozygote state, i.e. a heterozygote locus should show a 50:50 ratio if the DNA methylation levels are the same, any statistical deviation from that ratio would indicate an epi-allelic imbalance. Thus, the observed epi-allelic imbalance indicates that the two DNA strands in heterozygote regions can be differently methylated on the autosomes. Furthermore, SNPs were identified located within the mQTL region and tested as predictors for the DNA methylation levels. 36 SNP were identified which demonstrates that these SNP are putatively causal nucleotides responsible for the MQTL and the corresponding eQTL, or in strong linkage that mirrors the effect. Twelve genes contained one of more of these SNPs. Six of these genes (DPP10, PAPSS2, KLF12, MYLK, NSUN4 and $D D X 18$ ) have previously been linked DNA methylation regulation (Cámara et al., 2011; Du et al., 2016; Liu et al., 2010; Shulha et al., 2012; Wang et al., 2014; Zhang et al., 2010). DPP10 and $D D X 18$ have also been linked to neurological diseases, with DPP10 being associated with DNA methylation and ADHD (Heinrich et al., 2017), and adverse cognitive effects due to prenatal alcohol exposure (Frey et al., 2018), while DDX18 has been linked to opioid susceptibility (Cheng et al., 2020). The link between DNA methylation and cognition is interesting and will require further studies to be disentangled.

By comparing DNA methylations in other chicken studies (Li et al., 2011; Nätt et al., 2012) it was possible to replicate the pattern see around genes in this advanced intercross as well, where regions directly upstream of genes had decreased DNA methylation levels compared to the gene body. Furthermore, by subdividing genes into high and low expression levels and reapplying the DNA methylation patterns around the genes, it was evident that there is inter- 
individual variation that correlated with the gene expression. Higher expressed genes had lower methylation levels in the transcription start site compared to lower expressed genes with higher methylation levels. Furthermore, inter-population variation of DNA methylation was investigated by correlating the methylation levels in an interval of $2 \mathrm{Mb}$ around each gene. In total 6689 genes had a significant correlation, with half of these being positively correlated and half negatively, both upstream and downstream. This indicates that the epigenetic regulation is very complex. 


\section{Acknowledgement}

I would like to thank my supervisor Dominic Wright for your guidance and your thirst for science that has been driving this project forward. This project has been one of the most challenging and exciting endeavours I've done!

Thank you to my co-supervisors Per Jensen, for making this project possible, and Rie Henriksen for all the great discussions and the support

Thank you to all my colleagues (past and present) at the IFM Biology department for creating a pleasant working environment and all my collaborators and co-authors

Tack till dig Paula Jonsson! Min älskling som alltid är redo att lyssna på mitt snack om kodning, funktioner och statistik. Du gjorde verkligen denna resa lättare för mig $<3$

Tack till mina härliga kontorskollegor; Mia, Rebecca och Jesper! Vi delade många härliga skratt och några få lika härliga frustrationer!

Tack till Martin Johnsson och Niklas Björn för alla spännade diskussioner om vetenskap och kodning!

Tack till min familj, mamma Olga, pappa Per-Olof, syster Nina och schäfern Wilma

And finally, a big thanks to all the people before me who asked silly coding questions on stackoverflow and to the people who kindly and elegantly responded with single-line codes! 


\section{References}

Aten, J.E., Fuller, T.F., Lusis, A.J., Horvath, S., 2008. Using genetic markers to orient the edges in quantitative trait networks: The NEO software. BMC Syst. Biol. 2, 1-21.

https://doi.org/10.1186/1752-0509-2-34

Atkinson, T.J., Halfon, M.S., 2014. REGULATION OF GENE EXPRESSION IN THE GENOMIC CONTEXT. Comput. Struct. Biotechnol. J. 9, e201401001.

https://doi.org/10.5936/csbj.201401001

Berger, S.L., Kouzarides, T., Shiekhattar, R., Shilatifard, A., 2009. An operational definition of epigenetics. Genes Dev. 23, 781-783. https://doi.org/10.1101/gad.1787609

Bestor, T.H., 1990. DNA methylation: evolution of a bacterial immune function into a regulator of gene expression and genome structure in higher eukaryotes. Philos. Trans. R. Soc. Lond. B. Biol. Sci. 326, 179-187. https://doi.org/10.1098/rstb.1990.0002

Bird, A., 2002. DNA methylation patterns and epigenetic memory. Genes Dev. 16, 6-21. https://doi.org/10.1101/gad.947102

Bird, A.P., Wolffe, A.P., 1999. Methylation-Induced Repression- Belts, Braces, and Chromatin. Cell 99, 451-454. https://doi.org/10.1016/S0092-8674(00)81532-9

Broman, K.W., Sen, S., 2009. A Guide to QTL Mapping with R/qtl, Statistics for Biology and Health. Springer New York, New York, NY. https://doi.org/10.1007/978-0-387-92125-9

Burish, M.J., Kueh, H.Y., Wang, S.S.H., 2004. Brain Architecture and Social Complexity in Modern and Ancient Birds. Brain. Behav. Evol. 63, 107-124. https://doi.org/10.1159/000075674

Cámara, Y., Asin-Cayuela, J., Park, C.B., Metodiev, M.D., Shi, Y., Ruzzenente, B., Kukat, C., Habermann, B., Wibom, R., Hultenby, K., Franz, T., Erdjument-Bromage, H., Tempst, P., Hallberg, B.M., Gustafsson, C.M., Larsson, N.G., 2011. MTERF4 regulates translation by targeting the methyltransferase NSUN4 to the mammalian mitochondrial ribosome. Cell Metab. 13, 527-539. https://doi.org/10.1016/j.cmet.2011.04.002

Cheng, Z., Yang, B.Z., Zhou, H., Nunez, Y., Kranzler, H.R., Gelernter, J., 2020. Genome-wide scan identifies opioid overdose risk locus close to MCOLN1. Addict. Biol. 25, 1-11. https://doi.org/10.1111/adb.12811

Churchill, G.A., Doerge, R.W., 1994. Empirical threshold values for quantitative trait mapping. Genetics 138, 963-971. https://doi.org/10.1007/s11703-007-0022-y

Damiola, F., Schibler, U., Gene, C.-, 1998. A Serum Shock Induces Circadian Gene Expression in Mammalian Tissue Culture Cells. Cell 93, 929-937.

De Koning, D.J., Haley, C.S., 2005. Genetical genomics in humans and model organisms. Trends Genet. 21, 377-381. https://doi.org/10.1016/j.tig.2005.05.004

Docherty, S.J., Davis, O.S., Haworth, C.M., Plomin, R., D'Souza, U., Mill, J., 2012. A genetic association study of DNA methylation levels in the DRD4 gene region finds associations with nearby SNPs. Behav. Brain Funct. 8, 31. https://doi.org/10.1186/1744-9081-8-31

Doerge, R.W., Churchill, G.A., 1996. Permutation tests for multiple loci affecting a quantitative character. Genetics 142, 285-94.

Du, Y., Chen, Y., Wang, F., Gu, L., 2016. miR-137 plays tumor suppressor roles in gastric cancer cell lines by targeting KLF12 and MYO1C. Tumor Biol. 37, 13557-13569. https://doi.org/10.1007/s13277-016-5199-3

Dupont, C., Armant, D.R., Brenner, C.A., 2009. Epigenetics: Definition, mechanisms and clinical perspective. Semin. Reprod. Med. https://doi.org/10.1055/s-0029-1237423 
Eckhardt, F., Lewin, J., Cortese, R., Rakyan, V.K., Attwood, J., Burger, M., Burton, J., Cox, T. V., Davies, R., Down, T.A., Haefliger, C., Horton, R., Howe, K., Jackson, D.K., Kunde, J., Koenig, C., Liddle, J., Niblett, D., Otto, T., Pettett, R., Seemann, S., Thompson, C., West, T., Rogers, J., Olek, A., Berlin, K., Beck, S., 2006. DNA methylation profiling of human chromosomes 6, 20 and 22. Nat. Genet. 38, 1378-1385. https://doi.org/10.1038/ng1909

Falconer, D.S., Mackay, T.F.C., 1996. Introduction to Quantitative Genetics, 4th ed. Harlow, Essex, UK: Addison Wesley Longman.

Felsenfeld, G., 2014. A brief history of epigenetics. Cold Spring Harb. Perspect. Biol. 6, a018200-a018200. https://doi.org/10.1101/cshperspect.a018200

Fogelholm, J., Inkabi, S., Höglund, A., Abbey-Lee, R., Johnsson, M., Jensen, P., Henriksen, R., Wright, D., 2019. Genetical Genomics of Tonic Immobility in the Chicken. Genes (Basel). 10, 341. https://doi.org/10.3390/genes10050341

Frey, S., Eichler, A., Stonawski, V., Kriebel, J., Wahl, S., Gallati, S., Goecke, T.W., Fasching, P.A., Beckmann, M.W., Kratz, O., Moll, G.H., Heinrich, H., Kornhuber, J., Golub, Y., 2018. Prenatal alcohol exposure is associated with adverse cognitive effects and distinct whole-genome DNA methylation patterns in primary school children. Front. Behav. Neurosci. 12, 1-13. https://doi.org/10.3389/fnbeh.2018.00125

Fumihito, A., Miyake, T., Sumi, S.I., Takada, M., Ohno, S., Kondo, N., 1994. One subspecies of the red junglefowl (Gallus gallus gallus) suffices as the matriarchic ancestor of all domestic breeds. Proc. Natl. Acad. Sci. U. S. A. 91, 12505-12509. https://doi.org/10.1073/pnas.91.26.12505

Funck-Brentano, C., Lancar, R., Le Heuzey, J.Y., Lardoux, H., Soubrie, C., Lechat, P., 2001. Xenopus Polycomblike 2 (XPcl2) controls anterior to posterior patterning of the neural tissue. Dev. Genes Evol. 211, 309-314. https://doi.org/10.1007/s004270100157

Gao, F., Liu, X., Wu, X.P., Wang, X.L., Gong, D., Lu, H., Xia, Y., Song, Y., Wang, J., Du, J., Liu, S., Han, X., Tang, Y., Yang, H., Jin, Q., Zhang, X., Liu, M., 2012. Differential DNA methylation in discrete developmental stages of the parasitic nematode Trichinella spiralis. Genome Biol. 13, R100. https://doi.org/10.1186/gb-2012-13-10-r100

Goldberg, A.D., Allis, C.D., Bernstein, E., 2007. Epigenetics: A Landscape Takes Shape. Cell. https://doi.org/10.1016/j.cell.2007.02.006

Gómez-Herreros, F., Schuurs-Hoeijmakers, J.H.M., McCormack, M., Greally, M.T., Rulten, S., Romero-Granados, R., Counihan, T.J., Chaila, E., Conroy, J., Ennis, S., Delanty, N., CortésLedesma, F., De Brouwer, A.P.M., Cavalleri, G.L., El-Khamisy, S.F., De Vries, B.B.A., Caldecott, K.W., 2014. TDP2 protects transcription from abortive topoisomerase activity and is required for normal neural function. Nat. Genet. 46, 516-521. https://doi.org/10.1038/ng.2929

Gutiérrez-Ibáñez, C., Iwaniuk, A.N., Moore, B.A., Fernández-Juricic, E., Corfield, J.R., Krilow, J.M., Kolominsky, J., Wylie, D.R., 2014. Mosaic and concerted evolution in the visual system of birds. PLoS One 9, e90102. https://doi.org/10.1371/journal.pone.0090102 Heinrich, H., Grunitz, J., Stonawski, V., Frey, S., Wahl, S., Albrecht, B., Goecke, T.W., Beckmann, M.W., Kornhuber, J., Fasching, P.A., Moll, G.H., Eichler, A., 2017. Attention, cognitive control and motivation in ADHD: Linking event-related brain potentials and DNA methylation patterns in boys at early school age. Sci. Rep. 7, 1-12.

https://doi.org/10.1038/s41598-017-03326-3 
Henriksen, R., Johnsson, M., Andersson, L., Jensen, P., Wright, D., 2016. The domesticated brain: Genetics of brain mass and brain structure in an avian species. Sci. Rep. 6, 1-9. https://doi.org/10.1038/srep34031

Henriksen, R., Wright, D., 2017. Cerebrotype, in: Vonk, J., Shackelford, T. (Eds.), Encyclopedia of Animal Cognition and Behavior. Springer International Publishing, Cham, pp. 1-3. https://doi.org/10.1007/978-3-319-47829-6_1451-1

Hoops, D., Vidal-García, M., Ullmann, J.F.P., Janke, A.L., Stait-Gardner, T., Duchêne, D.A., Price, W.S., Whiting, M.J., Keogh, J.S., 2017. Evidence for Concerted and Mosaic Brain Evolution in Dragon Lizards. Brain. Behav. Evol. 90, 211-223. https://doi.org/10.1159/000478738

Irizarry, R.A., Wu, H., Feinberg, A.P., 2009. A species-generalized probabilistic model-based definition of CpG islands. Mamm. Genome 20, 674-680. https://doi.org/10.1007/s00335-009-9222-5

Iwaniuk, A.N., Hurd, P.L., 2005. The evolution of cerebrotypes in birds. Brain. Behav. Evol. 65, 215-230. https://doi.org/10.1159/000084313

Jaganathan, D., Bohra, A., Thudi, M., Varshney, R.K., 2020. Fine mapping and gene cloning in the post-NGS era: advances and prospects. Theor. Appl. Genet. 133, 1791-1810. https://doi.org/10.1007/s00122-020-03560-w

Jinek, M., Chylinski, K., Fonfara, I., Hauer, M., Doudna, J.A., Charpentier, E., 2012. A Programmable Dual-RNA-Guided DNA Endonuclease in Adaptive Bacterial Immunity. Science (80-. ). 337, 816-821. https://doi.org/10.1126/science.1225829

Johnsson, M., Gustafson, I., Rubin, C.J., Sahlqvist, A.S., Jonsson, K.B., Kerje, S., Ekwall, O., Kämpe, O., Andersson, L., Jensen, P., Wright, D., 2012. A Sexual Ornament in Chickens Is Affected by Pleiotropic Alleles at HAO1 and BMP2, Selected during Domestication. PLoS Genet. 8. https://doi.org/10.1371/journal.pgen.1002914

Johnsson, M., Williams, M.J., Jensen, P., Wright, D., 2016. Genetical genomics of behavior: A novel chicken genomic model for anxiety behavior. Genetics 202, 327-340. https://doi.org/10.1534/genetics.115.179010

Kerje, S., Carlborg, Ö., Jacobsson, L., Schütz, K., Hartmann, C., Jensen, P., Andersson, L., 2003. The twofold difference in adult size between the red junglefowl and White Leghorn chickens is largely explained by a limited number of QTLs. Anim. Genet. 34, 264-274. https://doi.org/10.1046/j.1365-2052.2003.01000.x

Kirkby, B., Roman, N., Kobe, B., Kellie, S., Forwood, J.K., 2010. Functional and structural properties of mammalian acyl-coenzyme A thioesterases. Prog. Lipid Res. 49, 366-377. https://doi.org/10.1016/j.plipres.2010.04.001

Klose, R.J., Bird, A.P., 2006. Genomic DNA methylation: The mark and its mediators. Trends Biochem. Sci. 31, 89-97. https://doi.org/10.1016/j.tibs.2005.12.008

Laine, V.N., Gossmann, T.I., Schachtschneider, K.M., Garroway, C.J., Madsen, O., Verhoeven, K.J.F., de Jager, V., Megens, H.-J., Warren, W.C., Minx, P., Crooijmans, R.P.M.A., Corcoran, P., Sheldon, B.C., Slate, J., Zeng, K., van Oers, K., Visser, M.E., Groenen, M.A.M., 2016. Evolutionary signals of selection on cognition from the great tit genome and methylome. Nat. Commun. 7, 10474. https://doi.org/10.1038/ncomms10474

Lander, E.S., Botstein, D., 1989. Mapping mendelian factors underlying quantitative traits using RFLP linkage maps. Genetics 121, 185-99.

Li, Q., Li, N., Hu, X., Li, J., Du, Z., Chen, L., Yin, G., Duan, J., Zhang, H., Zhao, Y., Wang, J., Li, N., 2011. Genome-wide mapping of dna methylation in chicken. PLoS One 6, 1-7. https://doi.org/10.1371/journal.pone.0019428 
Liu, J., Morgan, M., Hutchison, K., Calhoun, V.D., 2010. A study of the influence of sex on genome wide methylation. PLoS One 5. https://doi.org/10.1371/journal.pone.0010028

Lorincz, M.C., Dickerson, D.R., Schmitt, M., Groudine, M., 2004. Intragenic DNA methylation alters chromatin structure and elongation efficiency in mammalian cells. Nat. Struct. Mol. Biol. 11, 1068-1075. https://doi.org/10.1038/nsmb840

Luoh, S.W., Venkatesan, N., Tripathi, R., 2004. Overexpression of the amplified Pip4k2 $\beta$ gene from 17q11-12 in breast cancer cells confers proliferation advantage. Oncogene 23, 1354-1363. https://doi.org/10.1038/sj.onc.1207251

Mitrophanov, A.Y., Groisman, E.A., 2008. Positive feedback in cellular control systems. BioEssays 30, 542-555. https://doi.org/10.1002/bies.20769

Montgomery, S.H., Mundy, N.I., Barton, R.A., 2016. Brain evolution and development: Adaptation, allometry and constraint. Proc. R. Soc. B Biol. Sci. 283. https://doi.org/10.1098/rspb.2016.0433

Moore, J.M., Devoogd, T.J., 2017. Concerted and mosaic evolution of functional modules in songbird brains. Proc. R. Soc. B Biol. Sci. 284. https://doi.org/10.1098/rspb.2017.0469

Nätt, D., Rubin, C.J., Wright, D., Johnsson, M., Beltéky, J., Andersson, L., Jensen, P., 2012. Heritable genome-wide variation of gene expression and promoter methylation between wild and domesticated chickens. BMC Genomics 13, 59. https://doi.org/10.1186/1471-2164-13-59

Ogawa, F., Malavasi, E.L.V., Crummie, D.K., Eykelenboom, J.E., Soares, D.C., Mackie, S., Porteous, D.J., Millar, J.K., 2014. DISC1 complexes with TRAK1 and Miro1 to modulate anterograde axonal mitochondrial trafficking. Hum. Mol. Genet. 23, 906-919. https://doi.org/10.1093/hmg/ddt485

Park, J.H., Roeder, R.G., 2006. GAS41 Is Required for Repression of the p53 Tumor Suppressor Pathway during Normal Cellular Proliferation. Mol. Cell. Biol. 26, 40064016. https://doi.org/10.1128/mcb.02185-05

Perino, M., Van Mierlo, G., Karemaker, I.D., Van Genesen, S., Vermeulen, M., Marks, H., Van Heeringen, S.J., Veenstra, G.J.C., 2018. MTF2 recruits Polycomb Repressive Complex 2 by helical-shape-selective DNA binding. Nat. Genet. 50, 1002-1010. https://doi.org/10.1038/s41588-018-0134-8

Rehkämper, G., Frahm, H.D., Cnotka, J., 2008. Mosaic evolution and adaptive brain component alteration under domestication seen on the background of evolutionary theory. Brain. Behav. Evol. 71, 115-126. https://doi.org/10.1159/000111458

Rogers, C.D., Saxena, A., Bronner, M.E., 2013. Sip1 mediates an E-cadherin-to-N-cadherin switch during cranial neural crest EMT. J. Cell Biol. 203, 835-847. https://doi.org/10.1083/jcb.201305050

Schadt, E.E., Monks, S.A., Drake, T.A., Lusis, A.J., Che, N., Colinayo, V., Ruff, T.G., Milligan, S.B., Lamb, J.R., Cavet, G., Linsley, P.S., Mao, M., Stoughton, R.B., Friend, S.H., 2003. Genetics of gene expression surveyed in maize, mouse and man. Nature 422, 297-302. https://doi.org/10.1038/nature01434

Shulha, H.P., Crisci, J.L., Reshetov, D., Tushir, J.S., Cheung, I., Bharadwaj, R., Chou, H.J., Houston, I.B., Peter, C.J., Mitchell, A.C., Yao, W.D., Myers, R.H., Chen, J. fan, Preuss, T.M., Rogaev, E.I., Jensen, J.D., Weng, Z., Akbarian, S., 2012. Human-Specific Histone Methylation Signatures at Transcription Start Sites in Prefrontal Neurons. PLoS Biol. 10. https://doi.org/10.1371/journal.pbio.1001427 
Simpson, V.J., Johnson, T.E., Hammen, R.F., 1986. Caenorhabditis elegans DNA does not contain 5-methylcytosine at any time during development or aging. Nucleic Acids Res. 14, 6711-6719. https://doi.org/10.1093/nar/14.16.6711

Soller, M., Brody, T., Genizi, A., 1976. On the power of experimental designs for the detection of linkage between marker loci and quantitative loci in crosses between inbred lines. Theor. Appl. Genet. 47, 35-39. https://doi.org/10.1007/BF00277402

van Eijk, K.R., de Jong, S., Boks, M.P., Langeveld, T., Colas, F., Veldink, J.H., de Kovel, C.G., Janson, E., Strengman, E., Langfelder, P., Kahn, R.S., van den Berg, L.H., Horvath, S., Ophoff, R.A., 2012. Genetic analysis of DNA methylation and gene expression levels in whole blood of healthy human subjects. BMC Genomics 13, 636. https://doi.org/10.1186/1471-2164-13-636

Waddington, C.H., 1956. Genetic Assimilation of the Bithorax Phenotype. Evolution (N. Y). 10, 1. https://doi.org/10.2307/2406091

Wang, L., Zhao, Z., Meyer, M.B., Saha, S., Yu, M., Guo, A., Wisinski, K.B., Huang, W., Cai, W., Pike, J.W., Yuan, M., Ahlquist, P., Xu, W., 2014. CARM1 methylates chromatin remodeling factor BAF155 to enhance tumor progression and metastasis. Cancer Cell 25, 21-36. https://doi.org/10.1016/j.ccr.2013.12.007

Wright, D., Kerje, S., Brändström, H., Schütz, K., Kindmark, A., Andersson, L., Jensen, P., Pizzari, T., 2008. The genetic architecture of a female sexual ornament. Evolution (N. Y). 62, 86-98. https://doi.org/10.1111/j.1558-5646.2007.00281.x

Wright, D., Rubin, C.J., Martinez Barrio, A., Schütz, K., Kerje, S., Brändström, H., Kindmark, A., Jensen, P., Andersson, L., 2010. The genetic architecture of domestication in the chicken: Effects of pleiotropy and linkage. Mol. Ecol. 19, 5140-5156. https://doi.org/10.1111/j.1365-294X.2010.04882.x

Yasumi, T., Inoue, M., Maruhashi, M., Kamachi, Y., Higashi, Y., Kondoh, H., Uchikawa, M., 2016. Regulation of trunk neural crest delamination by $\delta \mathrm{EF} 1$ and Sip1 in the chicken embryo. Dev. Growth Differ. 58, 205-214. https://doi.org/10.1111/dgd.12256

Yu, Y., Zhang, H., Tian, F., Zhang, W., Fang, H., Song, J., 2008. An integrated epigenetic and genetic analysis of DNA methyltransferase genes (DNMTs) in tumor resistant and susceptible chicken lines. PLoS One 3, e2672. https://doi.org/10.1371/journal.pone.0002672

Zeng, Z., Cortés-Ledesma, F., El Khamisy, S.F., Caldecott, K.W., 2011. TDP2/TTRAP is the major 5'-tyrosyl DNA phosphodiesterase activity in vertebrate cells and is critical for cellular resistance to topoisomerase II-induced DNA damage. J. Biol. Chem. 286, 403409. https://doi.org/10.1074/jbc.M110.181016

Zhang, D., Cheng, L., Badner, J.A., Chen, C., Chen, Q., Luo, W., Craig, D.W., Redman, M., Gershon, E.S., Liu, C., 2010. Genetic Control of Individual Differences in Gene-Specific Methylation in Human Brain. Am. J. Hum. Genet. 86, 411-419. https://doi.org/10.1016/j.ajhg.2010.02.005

Zhao, W., Seki, A., Fang, G., 2006. Cep55, a Microtubule-bundling Protein, Associates with Centralspindlin to Control the Midbody Integrity and Cell Abscission during Cytokinesis. Mol. Biol. Cell 17, 3881-3896. https://doi.org/10.1091/mbc.e06-01-0015

Zhou, T., Li, S., Zhong, W., Vihervaara, T., Béaslas, O., Perttilä, J., Luo, W., Jiang, Y., Lehto, M., Olkkonen, V.M., Yan, D., 2011. Osbp-related protein 8 (ORP8) regulates plasma and liver tissue lipid levels and interacts with the nucleoporin Nup62. PLoS One 6. https://doi.org/10.1371/journal.pone.0021078 
Zucchelli, S., Vilotti, S., Calligaris, R., Lavina, Z.S., Biagioli, M., Foti, R., De Maso, L., Pinto, M., Gorza, M., Speretta, E., Casseler, C., Tell, G., Del Sal, G., Gustincich, S., 2009.

Aggresome-forming TTRAP mediates pro-apoptotic properties of Parkinson's diseaseassociated DJ-1 missense mutations. Cell Death Differ. 16, 428-438.

https://doi.org/10.1038/cdd.2008.169 


\section{Papers}

The papers associated with this thesis have been removed for copyright reasons. For more details about these see:

http://urn.kb.se/resolve?urn=urn:nbn:se:liu:diva-170138 


\section{FACULTY OF SCIENCE AND ENGINEERING}

Linköping Studies in Science and Technology, Dissertation No. 2097, 2020 Department of Physics, Chemistry and Biology

Linköping University

SE-581 83 Linköping, Sweden

www.liu.se

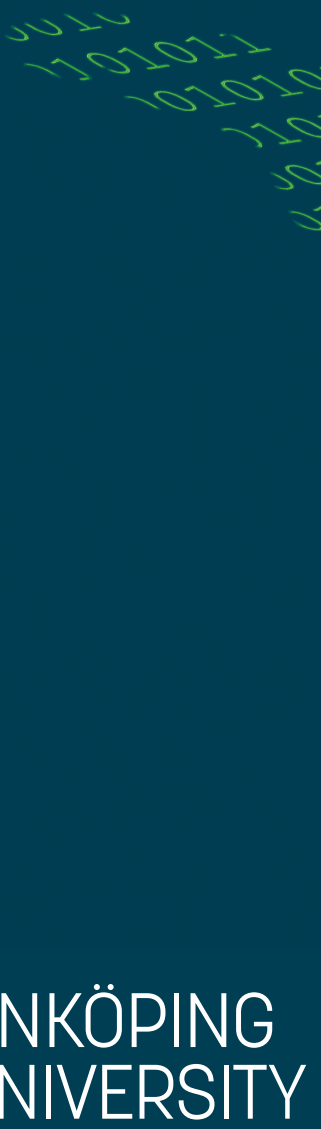

